\title{
Adrenocortical Insufficiency Associated with Long-term High-dose Fosfestrol Therapy for Prostatic Carcinoma
}

\author{
Hiroshi IIDA, Ichiro MIYAMOTO, Yatsugi NoDA, Masaru SAWAKI* and Yukihiro NAGAI**
}

\begin{abstract}
A 59-year-old man was admitted to our hospital because of muscular pain, weakness, and anorexia. He had been treated with $600 \mathrm{mg} /$ day of fosfestrol, a synthetic estrogen, for 10 years for prostatic carcinoma. Endocrinological studies demonstrated adrenocortical insufficiency due to inadequate ACTH secretion. After initiation of glucocorticoid replacement therapy, his symptoms subsided rapidly. To our knowledge, an association between estrogenic agents, including fosfestrol, and secondary adrenocortical insufficiency has not been previously reported. Physicians who treat patients with long-term and high-dose strong estrogenic agents should be cautious about the possible emergence of secondary adrenocortical insufficiency. (Internal Medicine 38: 804-807, 1999)
\end{abstract}

Key words: estrogen, endocrine therapy, cyproterone acetate

\section{Introduction}

Fosfestrol is a synthetic estrogenic agent widely used in the treatment of prostatic carcinoma. It exerts its clinical effect by reducing the release of gonadotropin-releasing hormone from the hypothalamus, thereby leading to a decrease in serum testosterone concentration $(1,2)$. Cyproterone acetate, an antiandrogenic agent which is also used for prostatic carcinoma, often induces secondary adrenal insufficiency by suppressing the hypothalamic-pituitary axis when administered in high doses $(3,4)$. To our knowledge, however, there has been no report of an association between estrogenic agents and adrenocortical insufficiency. We report a patient who developed secondary adrenocortical insufficiency 10 years after the initiation of high-dose fosfestrol therapy for prostatic carcinoma.

\section{Case Report}

A 49-year-old man was diagnosed with prostatic carcinoma in the Department of Urology of our hospital in 1988. Radiotherapy and endocrinotherapy using a synthetic estrogen, fosfestrol, were initiated, and oral treatment with $600 \mathrm{mg} / \mathrm{day}$ of fosfestrol was continued for 10 years in the urological outpatient clinic. In July 1997 , he was admitted to our department at the age of 59 because of slowly progressive muscular pain, weakness, and anorexia that had continued for 3 months. The physical examination on admission revealed the following: height, $167.0 \mathrm{~cm}$; weight, $49.8 \mathrm{~kg}$; blood pressure, 138/78 $\mathrm{mmHg}$; pulse, $72 \mathrm{bpm}$ and regular. The palpebral conjunctivae were pale. No goiter or lymphadenopathy was observed. Examinations of lungs, heart, and nervous system were unremarkable. No abnormal skin pigmentation was present. Axillary and pubic hair were preserved. Pretibial and pedal edema were noted. Laboratory data on admission revealed the following: white blood cell count, $9,400 / \mu$ l, with $23 \%$ segmented neutrophils, $1 \%$ banded neutrophils, $11 \%$ eosinophils, $57 \%$ lymphocytes, and $4 \%$ monocytes; red blood cell count, $301 \times 10^{4} / \mu 1$; hemoglobin, $8.9 \mathrm{~g} / \mathrm{dl}$; hematocrit, 26.8\%; platelet count, $19.8 \times 10^{4} / \mu \mathrm{l}$; serum total protein, $5.5 \mathrm{~g} / \mathrm{dl}$; serum albumin, 3.57 $\mathrm{g} / \mathrm{dl}$; serum sodium, $137 \mathrm{mEq} / l$; serum potassium, $4.6 \mathrm{mEq} / \mathrm{l}$; serum chloride, $104 \mathrm{mEq} / l$; serum calcium, $4.3 \mathrm{mEq} / l$; alkaline phosphatase, $143 \mathrm{IU} / l$; creatinine phosphokinase, $116 \mathrm{IU} /$ $l$; total cholesterol, $124 \mathrm{mg} / \mathrm{dl}$; and triglyceride, $64 \mathrm{mg} / \mathrm{dl}$. Hepatic and renal functions and urinalysis were normal. Fasting blood glucose was $73 \mathrm{mg} / \mathrm{dl}$. The endocrinological data on admission are shown in Table 1. The basal plasma cortisol concentration was decreased. The plasma adrenocorticotropin (ACTH) concentration was undetectable at baseline. Twentyfour-hour urinary determinations of 17 -hydroxycorticosteroids (17-OHCS), 17-ketosteroids (17-KS), and free cortisol revealed low excretions. The plasma concentrations of free testosterone, luteinizing hormone ( $\mathrm{LH})$, and follicle stimulating hormone (FSH) concentrations were decreased due to endocrinotherapy using fosfestrol. The circadian rhythm of

From the Department of Internal Medicine, *the Department of Urology, Toyama Rohsai Hospital, Toyama and **the First Department of Internal Medicine, School of Medicine, Kanazawa University, Ishikawa

Received for publication January 7, 1999; Accepted for publication May 29, 1999

Reprint requests should be addressed to Dr. Ichiro Miyamoto, the Department of Internal Medicine, Toyama Rohsai Hospital, 992 Rokuroumaru, Uozu, Toyama 937-0042 
Fosfestrol and Adrenocortical Insufficiency

Table 1. Endocrinological Data (Basal Hormone Levels)

\begin{tabular}{llll}
\hline Blood sample: & & & \\
ACTH & $<5 \mathrm{pg} / \mathrm{ml}(9-52)$ & $\mathrm{FT}_{3}$ & $4.8 \mathrm{pg} / \mathrm{ml}(3.0-6.0)$ \\
GH & $1.23 \mathrm{ng} / \mathrm{ml}(<1.46)$ & $\mathrm{FT}_{4}$ & $0.9 \mathrm{pg} / \mathrm{ml}(0.8-2.0)$ \\
TSH & $2.84 \mu \mathrm{U} / \mathrm{ml}(0.25-3.1)$ & Cortisol & $0.6 \mu \mathrm{g} / \mathrm{dl}(5.6-21.3)$ \\
LH & $0.4 \mathrm{mIU} / \mathrm{ml}(0.7-6.5)$ & Aldosterone & $3.3 \mathrm{ng} / \mathrm{dl}(2-13)$ \\
FSH & $0.3 \mathrm{mIU} / \mathrm{ml}(1.8-9.8)$ & $\mathrm{AVP}$ & $0.3 \mathrm{pg} / \mathrm{ml}(0.3-4.2)$ \\
PRL & $6.2 \mathrm{ng} / \mathrm{ml}(1.5-9.7)$ & Testosterone & $<0.1 \mathrm{ng} / \mathrm{ml}(2.7-10.7)$ \\
& & & \\
Urine sample: & & & \\
free cortisol & $32 \mu \mathrm{g} / \mathrm{day}(35-160)$ & & \\
17-OHCS & $0.5-1.3 \mathrm{mg} /$ day $(2.9-11.6)$ & & \\
17-KS & $0.4-1.8 \mathrm{mg} /$ day $(4.6-16.4)$ & & \\
\hline
\end{tabular}

ACTH: adrenocorticotropin, GH: growth hormone, TSH: thyroid stimulating hormone, LH: luteinizing hormone, $\mathrm{FSH}$ : follicle stimulating hormone, $\mathrm{PRL}$ : prolactin, $\mathrm{FT}_{3}$ : free triiodothyronine, $\mathrm{FT}_{4}$ : free thyroxine, AVP: arginine vasopressin, 17-OHCS: 17-hydroxycorticosteroids, 17-KS: 17-ketosteroids.

ACTH and cortisol was completely eliminated (Table $2 \mathrm{~A})$, and the rapid ACTH stimulation test $(250 \mu \mathrm{g})$ demonstrated a diminished adrenal response (Table $2 \mathrm{~B}$ ). Table $2 \mathrm{C}$ shows the detailed hormonal investigations. The responses of plasma ACTH and cortisol to corticotropin-releasing hormone (CRH) were very diminished, while thyrotropin (TSH), prolactin (PRL), and growth hormone (GH) were all adequately stimulated by their respective releasing hormones. The responses of plasma LH and FSH to LH-releasing hormone (LH-RH) were suppressed by fosfestrol. The responses of plasma ACTH and cortisol to insulin-induced hypoglycemia were unequivocally low (Table 2D). The cranial magnetic resonance image showed no evidence of organic disorder. Precontrast computed tomography demonstrated normal adrenal glands. Antithyroidal, antiadrenal, and antipituitary antibodies were all negative.

Based on these data, we made a diagnosis of adrenocortical insufficiency due to inadequate ACTH secretion. Fosfestrol was discontinued immediately, and oral administration of hydrocortisone $(20 \mathrm{mg} /$ day) was initiated from August 1997. The symptoms subsided in two weeks, and his anemia and eosinophilia also improved. At this writing, almost two years later (April 1999), he performs his typical activities but still receives glucocorticoid replacement therapy.

\section{Discussion}

Endocrine therapy is accepted as an effective method for managing advanced prostatic carcinoma. Fosfestrol is a synthetic estrogenic agent widely used in the endocrine treatment of prostatic carcinoma $(1,2)$. Fosfestrol exerts its clinical effect by reducing the release of gonadotropin-releasing hormone from the hypothalamus, thereby leading to a reduction in the release of FSH and LH from the pituitary, and a consequent decrease of serum testosterone concentrations $(1,2)$. Fosfestrol also exerts its effect by inhibiting the formation of $5 \alpha$ dihydrotestosterone (DHT) from testosterone in the cells of prostatic carcinoma $(1,2)$. There are obvious differences be- tween Japan and Western countries in the evaluation of this agent's efficacy against prostatic carcinoma. The efficacy of this drug is controversial in Western countries, and its adverse effects, especially cardiovascular complications, are stressed in the case of its oral administration (5). A specific study conducted by the European Organization for Research on Treatment of Cancer reported the following adverse effects of fosfestrol: fluid retention (16\%), electrocardiographic changes (3.6\%), myocardial infarction (10.7\%), arterial hypertension (1.8\%), and thromboembolic lesions (6.3\%) (6). Accordingly, cyproterone acetate, an antiandrogenic and progestational agent, is more widely used for the treatment of prostatic carcinoma in Western countries $(2,3)$. In Japan, however, there are many papers that demonstrate the usefulness of fosfestrol in the treatment of prostatic carcinoma with only minimal side effects when given appropriately $(7,8)$.

The causes of secondary adrenocortical insufficiency are primary pituitary disorders or causes secondary to hypothalamic disorders such as tumors, apoplexy, infection, trauma, immunological disorders, and adverse reactions to drugs and irradiation to the sella (9). The clinical history of the present case shows that pituitary apoplexy, trauma, and irradiation to the sella were unlikely. Moreover, based on his laboratory data and radiological findings, tumors, infection, and autoimmune hypophysitis can be excluded from the causative factors. Therefore, the secondary adrenocortical insufficiency of this case may have been due to the fosfestrol administration. In general, drug-induced adrenocortical insufficiency constitutes a rare but important cause of hypoadrenalism (10-12). Several classes of drugs, i.e. glucocorticoid, antiadrenal agents, anticoagulation agents, ketoconazole, rifampicin, and cyproterone acetate, can contribute to partial or complete adrenal failure (10-12). Of these drugs, only glucocorticoid and cyproterone acetate are known to induce secondary adrenocortical insufficiency (9). High-dose administration of cyproterone acetate is well known to cause secondary adrenal insufficiency by suppression of the hypothalamic-pituitary axis $(3,4,13)$. Savage and 
IIDA et al

Table 2. Endocrinological Studies

A. Daily profile of ACTH and Cortisol

\begin{tabular}{lllll}
\hline Time & $8: 00$ & $12: 00$ & $16: 00$ & $20: 00$ \\
\hline ACTH $(\mathrm{pg} / \mathrm{ml})$ & $<5$ & $<5$ & $<5$ & $<5$ \\
Cortisol $(\mu \mathrm{g} / \mathrm{dl})$ & $<1.0$ & $<1.0$ & $<1.0$ & $<1.0$ \\
\hline
\end{tabular}

B. Rapid ACTH stimulation test

\begin{tabular}{llll}
\hline Time after the injection $(\min )$ & 0 & 30 & 60 \\
\hline Cortisol $(\mu \mathrm{g} / \mathrm{dl})$ & $<1.0$ & 2.0 & 4.3 \\
Aldosterone $(\mathrm{ng} / \mathrm{dl})$ & 3.3 & 7.2 & 6.8 \\
\hline
\end{tabular}

C. Provocative tests by CRH, GRH, TRH, and LH-RH

\begin{tabular}{lllllll}
\hline Time after the injection $(\mathrm{min})$ & 0 & 15 & 30 & 60 & 90 & 120 \\
\hline ACTH $(\mathrm{pg} / \mathrm{ml})$ & $<5$ & 7 & 11 & 8 & 9 & $<5$ \\
Cortisol $(\mu \mathrm{g} / \mathrm{dl})$ & $<1.0$ & $<1.0$ & 1.2 & 1.5 & 1.3 & $<1.0$ \\
GH $(\mathrm{ng} / \mathrm{ml})$ & 1.23 & 19.7 & 22.8 & 16.7 & 11.1 & 4.72 \\
TSH $(\mu \mathrm{U} / \mathrm{ml})$ & 2.03 & 10.81 & 10.91 & 10.56 & 9.54 & 7.53 \\
PRL $(\mathrm{ng} / \mathrm{ml})$ & 6.2 & 22.8 & 21.9 & 18.5 & 17 & 12.8 \\
LH $(\mathrm{mIU} / \mathrm{ml})$ & 0.4 & 0.7 & 0.7 & 0.8 & 1.0 & 0.8 \\
FSH $(\mathrm{mIU} / \mathrm{ml})$ & 0.3 & 0.4 & 0.4 & 0.5 & 0.5 & 0.5 \\
\hline
\end{tabular}

$100 \mu \mathrm{g}$ of CRH, $100 \mu \mathrm{g}$ of GRH, $500 \mu \mathrm{g}$ of TRH, and $100 \mu \mathrm{g}$ of LH-RH were administered intravenously at 0 minute.

D. Insulin tolerance test

\begin{tabular}{llllll}
\hline Time after the injection $(\mathrm{min})$ & 0 & 30 & 60 & 90 & 120 \\
\hline Glucose $(\mathrm{mg} / \mathrm{dl})$ & 68 & 27 & 35 & 38 & 42 \\
ACTH $(\mathrm{pg} / \mathrm{ml})$ & $<5.0$ & 8.0 & 8.0 & 6.0 & 7.0 \\
Cortisol $(\mu \mathrm{gg} / \mathrm{dl})$ & $<1.0$ & $<1.0$ & $<1.0$ & $<1.0$ & 1.0 \\
GH $(\mathrm{ng} / \mathrm{ml})$ & 2.44 & 4.32 & 21.9 & 25.3 & 21.2 \\
\hline
\end{tabular}

Abbreviations and normal values are shown in Table 1.

Swift reported that a dose of $2 \mathrm{mg} / \mathrm{kg}$ per day of cyproterone acetate consistently had a suppressant effect on the hypothalamic-pituitary-adrenal axis, but that the adrenocortical function returned to normal a few weeks after the withdrawal of the drug (4). The present case has never been administered any of the above drugs. Regarding fosfestrol, it is well known that estrogen treatment results in the elevation of serum cortisol and plasma ACTH levels $(14,15)$. Therefore, it is unlikely that fosfestrol induced the secondary adrenocortical insufficiency directly.

We cannot deny the possibility that the isolated ACTH deficiency, a development whose etiology was unclear, might have occurred coincidentally in the present case. However, it is also possible that a thromboembolism, one of the characteristic ad- verse effects induced by fosfestrol, led to a pituitary infarction and consequent ACTH deficiency. Small pituitary infarctions sometimes go entirely undetected by radiological examinations (16).

Although the mechanism of secondary adrenocortical insufficiency remained unclear in the present case, physicians should be cautious about the possible emergence of secondary adrenocortical insufficiency, especially when patients treated with long-term and high-dose estrogen therapy complain of symptoms such as muscular pain, weakness, and anorexia.

\section{References}

1) Nakamura K. Bioavailability, distribution and pharmacokinetics of dieth- 


\section{Fosfestrol and Adrenocortical Insufficiency}

ylstilbestrol converted from diethylstilbestrol diphosphate in patients with prostatic cancer. Hiroshima J Med Sci 35: 325-338, 1986.

2) Kitahara $S$, Yoshida K, Ishizaka K, et al. Stronger suppression of serum testosterone and FSH levels by a synthetic estrogen than by castration or an LH-RH agonist. Endocr J 44: 527-532, 1997.

3) Girard J, Baumann JB, Buhler U, et al. Cyproteroneacetate and ACTH adrenal function. J Clin Endocrinol Metab 47: 581-586, 1978.

4) Savage DCL, Swift PGF. Effect of cyproterone acetate on adrenocortical function in children with precocious puberty. Arch Dis Child 56: 218 222, 1981.

5) Droz J-P, Kattan J, Bonnay M, Chraibi Y, Bekradda M, Culine S. Highdose continuous-infusion fosfestrol in hormone-resistant prostate cancer. Cancer 71: 1123-1130, 1993.

6) de Voogt HJ, Smith PH, Pavone-Macaluso M, De Pauw M, Suciu S. Cardiovascular side effects of diethylstilbestrol, cyproterone acetate, medroxyprogesterone acetate, and estramustine phosphate used for the treatment of advanced prostatic cancer: results from European Organization for Research on Treatment of Cancer trials 30761 and 30762. J Urol 135: 303-307, 1986.

7) Oishi K, Arai Y, Takeuchi H, Yoshida O. Side effects of estrogen administration to prostatic cancer patients: clinical and statistical survey of 109 prostatic cancer cases of Kyoto University Hospital. Hinyokika Kiyo 39: 23-28, 1993 (in Japanese).

8) Hayakawa K, Kimura S, Ikeuchi K. The usefulness of hormone therapy in the treatment of prostatic cancer-clinical analysis of 160 cases over
12 years in the single institute. Nippon Hinyokika Gakkai Zasshi 85: 1256-1262, 1994 (Abstract in English).

9) Kannan CR. Addison's disease. in: The Adrenal Gland. Kannan CR, Ed. Plenum Publishing Corporation, New York, 1988: 31-96.

10) Pont A, Graybill JR, Craven PC, et al. High-dose ketoconazole therapy and adrenal testicular function in humans. Arch Intern Med 144: 2150$2153,1984$.

11) Fellows IW, Byrne AJ, Allison SP. Adrenocortical suppression with etomidate. Lancet 2: 54-55, 1983 (letter).

12) Elansary EH, Earis JE. Rifampicin and adrenal crisis. Br Med J (Clin Res Ed) 286: 1861-1862, 1983.

13) Lamberts SWJ, Uitterlinden P, de Jong FH. Rat prostatic weight regression in reaction to ketoconazole, cyproterone acetate, and RU 23908 as adjuncts to a depot formulation of gonadotropin-releasing hormone analogue. Cancer Res 48: 6063-6068, 1988.

14) Schurmeyer T, Graff J, Senge T, Nieschlag E. Effect of oestrogen or cyproterone acetate treatment on adrenocortical function in prostate carcinoma patients. Acta Endocrinol (Copenh) 111: 360-367, 1986.

15) Saoud CJ, Wood CE. Modulation of ovine fetal adrenocorticotropin secretion by androstenedione and 17 beta-estradiol. Am J Physiol 272: R1128-R1134, 1997.

16) Wieland RG, Wieland JM. Isolated adrenocorticotropic hormone deficiency with antepartum pituitary infarction in a type I diabetic. Obstet Gynecol 65: 58S-59S, 1985. 